\title{
REGIONAL DEVELOPMENT INSTITUTIONS AS AN ECONOMIC GROWTH FACTORS
}

The article investigates the characteristics of development and the territorial distribution of regional development institutions. The methodical approach to assessing the level of development of regional institutions taking into account the systemic nature and activity of territories in the creation and development of regional institutions is introduced. The results of evaluation of the development level of regional institutions have allowed to identify the regions using various institutions and instruments of development most actively in their territories (22 Federal subjects of Russia) and the regions where are no institutes for development (45 Federal subjects of Russia). Following parameters of performance evaluation of regional development institutions are offered: the indicators of intensity of innovation in production, performance intensity of innovation in society and the resulting performance of the dynamics of economic development.

The results of evaluating the effectiveness of regional development institutions in the subjects of the Russian Federation are presented in the paper. The main problem of the formation of institutions and institutional environment in the regions of the Russian Federation due to the lack of unified science-based theoretical and methodological framework and the lack of integration links between science, business, education and government are defined.

Keywords: Institute for Development, innovation, economic development

The crisis of system of public administration has immensely influenced on Russian economic operation in recent years. Lack of effective government regulation, crisis tendencies in its development, weak principles of the territorial organization were the factors, which have strengthened the processes of disintegration and essential polarization in levels of socio-economic development of territories in the country. These problems especially tackled the infrastructure sphere.
The solving of the majority of the economic problems in essential degree depends on active participation of institutes for development as a quality and adequacy of the institutional environment define the directions, forms, conditions and possibility of economic modernization. Creation of working and effective system of institutes for development is a paramount objective of regional authorities now. 


\section{Market institution of regional development}

In the wide sense institutes are meant as the formal and informal norms of interaction between economic agents. There is no standard terminology concerning this subject. The concept of «institute» meets in both sociological and economical research therefore; it causes a large number of definitions. The institutions mean rules, systems of rules, norms, restrictions, habits, customs, organizations, balance, a frame etc. Institutes for development usually are thought to be special organizations promoting resource distribution in favor of realization projects of new growth potential of a region or country as a whole [4]. However, this approach considers only organizational aspects of mechanisms of functioning of such institutes and studying activity of a certain type of organizations. However, the approach does not explain the similar processes happening in another type of organizations - institutes for development. In this regard, there is another approach, which considers this concept. The institute for development is the firm principle of interaction between economic agents; the change of system condition is the result of its work [9].

The important feature of institutes for development is state regulation in their work. Any socially caused the structure, a tool, mechanism reducing uncertainty in a system and stimulating more effective economic activity can become the institute for development [8]. In a narrow view, institutes are separate organizations and procedural mechanisms. And economic development is promoted only by those of them, which allow to realize effective administrative decisions. Therefore, these institutes are both a sphere and a tool for development of a state policy at the same time [5, page 73].

The state institutes for development are allocated. It is a set of special organizations created and accumulated by the government. They carry out joint financing (including the use of credit and guarantee mechanisms) the commercial projects having a high economic or public importance. It is pleasant to consider that institutes for development are structures, which accumulate financial funds and direct them to the development of perspective branches of economics, introduction of innovations, implementation of important infrastructure and social projects. From this point of view, the institutes for development are urged to carry out equalizing and stimulating role in the regional policy allowing lagging territories to reduce a gap gradually. In the international practice, there are allocated a few types of institutes for development.
1. The development finance institution through which additional financing at insufficient development of the regional financial market can be received.

2. Development infrastructure institutions, which most of all concentrate on different forms of financing attraction including state-private partnership in infrastructure projects (transport and logistic projects, projects of science and technology parks, industrial parks, etc.).

3. Corporations of industrial (innovative) development are aimed at industry support in the various directions by cluster development, the supporting of small business or innovation stimulation.

4. The institutes for development supporting internationalization of regions directed on foreign investments attraction and export support.

5 . The specialized social funds co-financing through various tools of professional development program, re-trainings, etc.

The listed types of institutes for development are also essentially different in their economic nature. Some function on the principles of recoverability of investing funds, others carry out costs to achieve social purposes. For this reason, the combination of different types in one institute for development becomes the increased risk. As practice shows it is required to form a system of institutions, each of which has to deal with a particular issue.

In Russia, almost all the range of institutes for development is presented. The nowadays system includes more than 15 organizations focused on the supporting of small business (Russian Bank for Small and Medium Enterprises Support, SME Business Support Funds), export stimulation (Roseksimbank) and housing construction (Agency for Housing Mortgage Lending), development of advanced technologies (ROSNANO, Skolkovo, the Russian venture corporation), the international investment cooperation (Eurasian Development Bank). The overall capital of institutes for development is more than 1 trillion rubles that make nearly 3\% of Gross Domestic Product. For effective impact on economic structure, the capitalization of the Russian institutions has to be brought up to the level of 5-7\% of Gross Domestic Product. Nowadays developed a system of institutions is presented by three levels of institutes for development - Federal, regional offices of Federal institutions and regional institutions. More than 70\% of the system belongs to the federal institutions.

According to «Expert RA» research, the amount of finance of regional development institutions was about 83,25 billion of rubles in 2010 . At that, more 


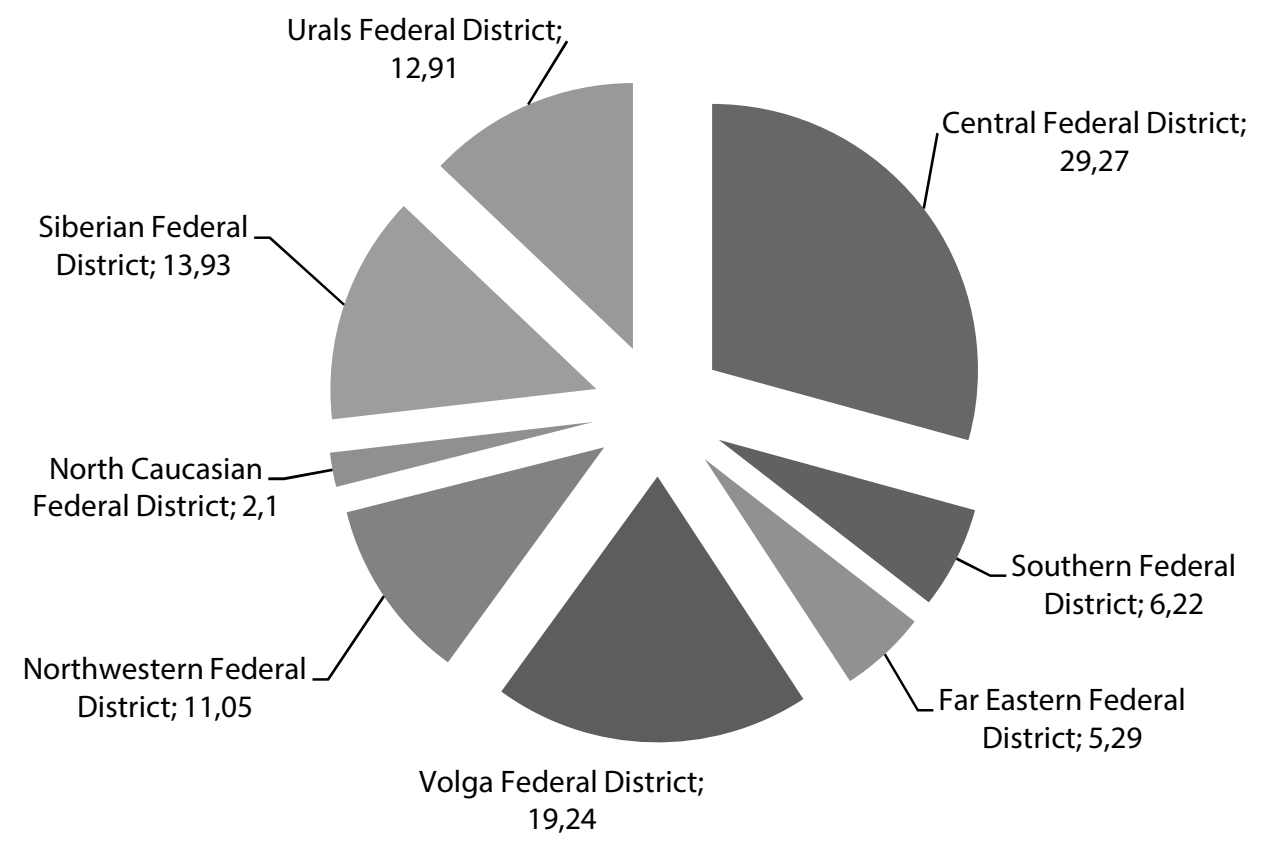

Fig. 1. Share of regions in the total mortgage credits, \% [1]

than $40 \%$ of overall finance is aimed at nine leading regions (The Republic of Tatarstan, Moscow region, Lipetsk region, Kaluga region, Tomsk region, Moscow, St. Petersburg, Krasnoyarsk Krai and Yakutia). At the same time, comparison of absolute and relative measures of institutes for development resources' concentration in regions is questionable. By the absolute sizes of a share of the attracted resources of institutes for development, Tatarstan has a leading position, and on a share of a Gross Regional Product and an average per capita indicator leaders are the Kaluga region and the Lipetsk region. It can be explained by the small sizes of regional economics and population in aggregate with a large amount of investments attracted through regional corporations of development and special economic zones, and also by a high efficiency of realization of investment policy [11].

The regional mortgage operating on partner agreements from the Agency for Housing Mortgage Lending is one of the most widespread types of institutes for the development of the regional level. They represent brokerage structures, which place for a small percent of agency finances among private clients purchasers of housing and the banks crediting on the standards of the Agency for Housing Mortgage Lending. In a total amount of the given-out mortgage loans, the indisputable leader is the Central Federal District. The second place according to the amount of the given-out credits goes to the Volga Federal District the third one is for the Siberian Federal District (fig. 1).

The regional venture capital funds are another type of institutes for development, which act as the local operators of $\mathrm{OOO}$ «Russian Venture Capital
Company». Venture capital funds invest in securities or enterprises waiting for a high profit with a high risk, and their task is to be a source of rather cheap financing for young innovative companies. According to OJSC Russian Venture Company, 22 regional venture capital funds into small enterprises of scientific and technical sphere work in Russia. They were organized by the Ministry of Economic Development of the Russian Federation and together with regions' administrations in the period of 2006-2013. Overall project financing is 8,9 billion rubles [3].

There is a territorial inequality in a number of funds and their sizes (fig. 2). The greatest number of funds (nine) is concentrated in the Volga district with a total investment of 3700 million rubles, on the second place is the Central Federal District with five funds of 2044 million rubles. The Southern district, the North Caucasian district and the North West district have one venture capital fund in the territory the Far East is without any of regional venture funds.

The Funds to support small and medium businesses are the regional development institutions. They are in all of Federation subjects of Russia, but in different regions the funds work with different level of efficiency. The greatest support to small and medium business is in Moscow, St. Petersburg, Krasnodar Krai, the Moscow region and the Rostov region.

At the level of territorial subjects of the Russian Federation, one of the most noticeable institutes for development is the regional corporation for development. Corporations in several regions of the Russian Federation (in regions such as the 


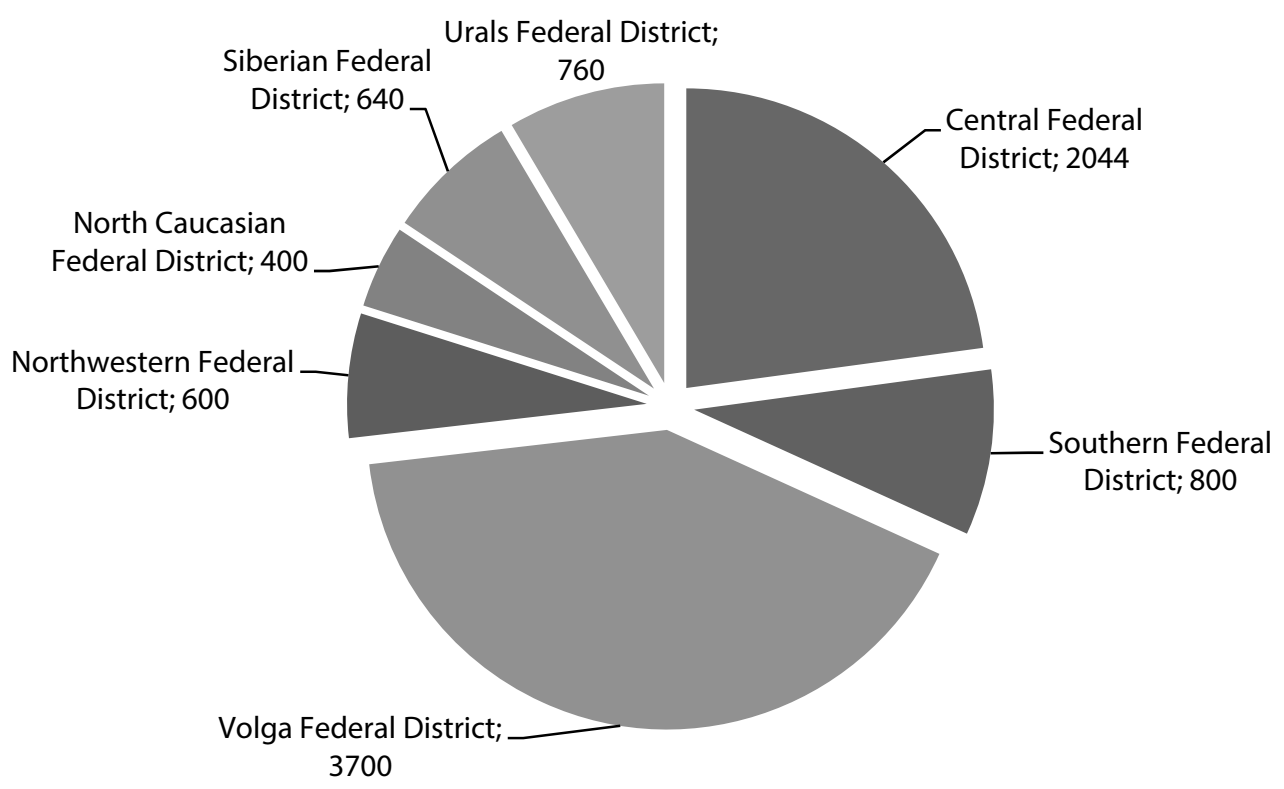

Fig.2. Distribution of regional venture capital funds over the Federal districts of Russia, million rubles

Kaluga, Penza, Rostov, Volgograd, Ulyanovsk, Samara, Yaroslavl, Orenburg, Belgorod, Tula regions, the Republic of Karelia and Chuvash) are created. Corporations for development of the Central Ural region and the North Caucasus are also functioning. Corporations for development are the regional operators of priority investment projects. Unlike the private and state partnership or technological platform they are not attached to the specific project or a certain purpose, but solve the major problems.

However, there are a number of shortcomings and problems concerning work of such institutions. It connected, first of all, to a lack of the special status of such institutions. There is no standard, and legal base for the functioning of regional development institutions, the laws «about the corporation» at the level of the region are adopted only in certain regions. There is no inter-level cooperation between the organizations; the interaction of institutes for development among themselves has unsystematic character.

As one more institute for development at the regional level that operate free (or special) economic zones (SEZ), which represent limited territories with the special legal status in relation to other territory and preferential economic terms for national and (or) foreign businessmen. In essence, this institution is similar to development corporations as in both cases the main attention is paid to infrastructure development of the region, and an ultimate goal is a creation of new productions and (or) other types of economic activity in the region.

17 special Federal Economic Zones work in Russia: technology development (Tomsk,
St. Petersburg, Moscow and Moscow region (Dubna), tourist-recreational («The Altai valley» (Altai Republic), «The Baikal harbor» (Republic of Buryatia), «Biryuzovaya Katun» (Altai territory), «the Gate of Baikal» (Irkutsk region)), industrial and production (Tatarstan, the Lipetsk region), logistic («Sovetskaya Gavan» (Khabarovsk territory), «Ulyanovsk» (Ulyanovsk region)). The industrial and production zone exists and rather successfully in the Republic of Tatarstan. There is a production of cars and auto components, chemical and petrochemical production. In the zone of the Lipetsk region, there is a production of construction materials, household appliances and the trade equipment. Tourist-recreational and logistic zones are not so popular at the moment; they are in an initial stage of budgetary fund development. Despite positive experience of creation SEZ such as «Alabuga» in Tatarstan, SEZ in Tomsk and Dubna where the private investments exceeded the budgetary appropriations, existing infrastructure problems interfere the natural growth of SEZ. In the majority, it is the numerous delays caused by the imperfection of the Land Code. The system of privileges operation in SEZ territory also is not so attractive to the Russian and foreign investors.

\section{Productivity assessment of institutes for development}

In long-term prospect, the innovation-driven growth is valued by the most perspective option for development of the regions, the certain countries and world economic system as a whole [2]. In this context, it is better to use one more approach to allocate the following institutes for development: priorities for innovation-driven growth; 
Assessment standards for regional development institutes

\begin{tabular}{|l|l|}
\hline \multicolumn{1}{|c|}{ Unit of assessment } & \multicolumn{1}{c|}{ Indicator } \\
\hline Legislation & Presence and consistency of the regional innovation legislation \\
\hline Cluster development & Presence of legislative and functioning clusters in the region \\
\hline Regional development corporations & $\begin{array}{l}\text { Presence, functioning or organizing of new institutes of development on the federal or } \\
\text { regional level }\end{array}$ \\
\hline Technological platforms & Participation of a region in technological platforms (federal and regional) \\
\hline Higher Education Institutions & Presence of the federal and national highest educational entering into leading ratings \\
\hline Activities and events & The main event and exhibitions held in a region on a subject of innovations \\
\hline $\begin{array}{l}\text { Association of Innovative Regions of } \\
\text { Russia }\end{array}$ & Inclusion of a region in the „Association of Innovative Regions of Russia” \\
\hline SEZ & Presence of special economic zones in the region \\
\hline
\end{tabular}

networks and clusters; property rights; financial support of the small innovation enterprises; indirect stimulation of innovation activity; effective estimation of quality and productivity; superiority centers, etc. [7]

In the analysis of institutes for development, the emphasis was laid on the following priorities: consistency of the innovation legislation in the region; development of clusters; assessment of innovation activity through innovation events held in the region; presence and functioning of regional corporations for development; existence in the region either federal, national or the higher education institution entering into leading ratings of educational institutions; entry of territorial subjects of the Russian Federation into «Association of Innovative Regions of Russia»; participation of the region in technological platforms.

The analysis of regional institutes for development assumes an assessment of the presence of functioning or creation of new various institutes for development. As a priority tasks for regional development institutions are infrastructure development and stimulation of innovations in regions, so in their assessment it is important to give attention to consistency of actions of regions and the existence of the united network strategy of innovation-driven growth in the region. The accounting how the subjects of innovation activity work and consistency of this active work are the basic moment in the assessment of institutes for development (tab. 1).

The analysis of institutional environments by a number of the act defining policy and regulation of innovation activity at the regional level, and also a degree (frequency) of their refreshing (acceptance) are one of the ways of an assessment. We believe, for ensuring full standard regulation in the sphere of regional innovation activity, the formation of a complex system of legal acts of various levels and appointment (the frame law on innovation activity, the concept or program of in- novation-driven growth, the target program and laws) is necessary. Recently regions have shown hyperactivity in the direction of the organizing of the innovation legislation, however, in the most cases in such documents it is a question of support of innovation activity as a whole, without allocation and specification of specialization, types of innovation activity, key subjects, specifics of the region and an assessment of the result of innovation activity.

In our opinion, one of the conditions of innovation activity development is the high potential of a clustering in the region. It is characterized by the presence of the following factors of competitiveness: the strong competition in branch; the developed infrastructure necessary for activity of the cluster companies; competitive branches suppliers; presence in a branch of the resource base, and also unique competitive advantage which allows to organize a cluster. It is possible to estimate clustering potential on a share of the enterprises presented in a region, which ready to participate in a cluster. A level of clusters' development can be valued through an assessment of a number quantity of the real-life, operating and legislative clusters.

Technological platforms (TP) are the new institute for development. TP is associations of the state representatives, business, science and education on the general vision of scientific and technical development and the general approaches to the development of appropriate technologies. Within TP, the special attention has to be paid to the definition of the main directions of strategic research and mobilization of efforts on the corresponding scientific research and innovations. TP is focused on technological modernization of economics, increase of competitiveness of certain branches, fast distribution of new technologies and development of «breakthrough» technologies for the development of the new markets of hi-tech production. 
Table 2

Regional structure of the coordinating agency of technological platforms in 2013

\begin{tabular}{|l|c|}
\hline $\begin{array}{c}\text { Regional accessory of the } \\
\text { coordinating agency }\end{array}$ & $\begin{array}{c}\text { Number of technological } \\
\text { platforms, unit }\end{array}$ \\
\hline Tomsk region & 1 \\
\hline Krasnoyarsk Krai & 1 \\
\hline Moscow & 22 \\
\hline Moscow - Yaroslavl region & 1 \\
\hline Moscow - Moscow region & 2 \\
\hline Moscow - St. Petersburg & 2 \\
\hline Kazan & 1 \\
\hline TOTAL & 30 \\
\hline
\end{tabular}

Source: it is calculated on the basis of the protocol data No. 2 of the meeting of the commission on high technology and innovation of the Russian government of 21.02.2012/

The commission on high technology and innovation of the Russian government approved list of 27 technology platforms in the priority spheres of developing science and technology in 2011. For 2013, there are created 30 new TP. At the same time, it should be noted that regional accessory of the coordinating agency of technological platforms is not diversified (tab. 2).

These tables allow to draw the conclusion that Moscow is the central region in the realization of state innovation policy. It is rather strange that the industrial Ural Federal District regarding technological platforms is not presented by any coordinating agency. In the Volga Federal District the technological platform «Textile and Light Industry» on the basis of «Kazan National Research Technological University» was created in 2012. Thus, it is possible to the state rather low level of inclusiveness of country regions in a process of technological platform formation.

To assess the activity and existence of system approach to the development of innovation activity in the territory it is expedient to define and control the main events in the innovation sphere, for example, events on a subject of innovations. In spite of the fact that today the similar events are held almost in every second subject of the Russian Federation, the competition between large innovation forums grows against the quality growth of their information content. From this point of view, the most qualitative is «Innovus» (Tomsk, April), «Interra» (Novosibirsk, September) and the Petersburg International Innovation Forum (St. Petersburg, September) [10].

Inclusion of Federation subjects of Russia in «Association of Innovative Regions of Russia» gives additional opportunities to territories. In particular, regions have new opportunities for product promotion of innovative production of the region enterprises in the Russian territory and international markets. Executive authorities will be able to develop joint programs to create interregional financial and supply funds for the implementation of general projects, to form various information structures and the databanks necessary for executive decision-making. The Association includes the Republics of Mordovia, Tatarstan and Bashkortostan, Krasnoyarsk and Perm edges, Irkutsk, Kaluga, Novosibirsk, Tomsk, Lipetsk, Samara and Ulyanovsk regions.

The presence of the higher educational institutions being suppliers of qualified personnel in the region, certainly, influence on a level of regional innovative capacity. At the same time, a type and a rating of this higher education institution play the important role. For example, the presence of federal or national university influences on the innovative capacity of the territory as it is the educational institution integrating science and education and having its own development program. Inclusion of higher education institution in the largest ratings also testifies to its high educational and innovation levels.

There are mote subjects of the Russian Federation, which does not have regional development institutions (45 Federation subjects of Russia). 22 subjects of the Russian Federation (St. Petersburg, the Tomsk region, Krasnoyarsk Krai and the Republic of Tatarstan, etc.) activly use various institutions and instruments for development in the territories (tab. 3).

Institutes for development in St. Petersburg, being on the first place in a rating of the subjects of the Russian Federation is most active. In the city works and constantly updates the innovative legislation and cluster legislation that shows the system approach of authorities to innovation development of the territory. Regular carrying out of the Saint Petersburg International Economic Forum testifies to territory recognition as the innovation center of the country. SEZ functions and two technological platforms are created in the city.

Federal subjects of Russia get into the same category of the most active regions: Republic of Tatarstan, Tomsk region and Krasnoyarsk Krai. The Republic of Tatarstan has rather developed legislative base for the increasing of innovation activity and investment attractiveness of the region. SEZ of «Alabuga» has an industrial and production focus and stimulates inflow of investments into the regional economy. In the republic territory there actively grows the technological platform. 
Groups of regions on a level of institution development in 2013

\begin{tabular}{|c|c|c|}
\hline Leadership & $\begin{array}{c}\text { Regions with mid-level development } \\
\text { of regions }\end{array}$ & Absence of institutes for development \\
\hline $\begin{array}{l}\text { St. Petersburg, Tomsk region, } \\
\text { Krasnoyarsk Krai } \\
\text { Republic of Tatarstan } \\
\text { Moscow, Sverdlovsk region } \\
\text { Kaluga region, Irkutsk region, } \\
\text { Samara region } \\
\text { Novosibirsk region, Penza region, } \\
\text { Yaroslavl region, Voronezh region, } \\
\text { Rostov region, Ulyanovsk region, } \\
\text { Republic } \\
\text { Bashkortostan, } \\
\text { Moscow region, Lipetsk region, } \\
\text { Kaliningrad region, Saratov region, } \\
\text { Orenburg territory, Perm Krai }\end{array}$ & $\begin{array}{l}\text { Regions: Belgorod, Bryansk, } \\
\text { Tverskaya, Volgograd, Omsk, } \\
\text { The Magadan } \\
\text { Republics: Karelia, Mordovia, Komi, } \\
\text { Chuvash, Altai, Sakha (Yakutia) } \\
\text { Krai: Stavropol, Altai, Seaside, } \\
\text { Khabarovsk }\end{array}$ & $\begin{array}{l}\text { Regions: Vladimir, Ivanovo, Kostroma, Kursk, } \\
\text { Oryol, Ryazan, Smolensk, Tambov, Tula, } \\
\text { Arkhangelsk, Vologda, Leningrad, Murmansk, } \\
\text { Novgorod, Pskov, Astrakhan, Kirov, Nizhny } \\
\text { Novgorod, Tyumen, Chelyabinsk, Kemerovo, } \\
\text { Amur, Sakhalin, } \\
\text { Republics: Adygea, Kalmykia, Dagestan. } \\
\text { Ingushetia, the Kabardino-Balkarian, Karachay- } \\
\text { Cherkess, North Ossetia - Alania, Chechen, Mari } \\
\text { El, Udmurt, Buryatia, Tyva, Khakassia, } \\
\text { Krai: Krasnodar, Transbaikal, Kamchatka } \\
\text { Nenets Autonomous Area, Khanty-Mansi } \\
\text { Autonomous Okrug, Yamalo-Nenets Autonomous } \\
\text { Area, Chukchi, Jewish Autonomous Region }\end{array}$ \\
\hline
\end{tabular}

Institutes for development of the Tomsk region and Krasnoyarsk Krai are focused on assistance of development for innovation activity. Economic and innovative forums of the AllRussian scale carried out in these federal subjects, presence of federal and national universities, creation of technological platforms proves these regions to be the centers of innovation development. The regions actively use all the institutes for development. Institute for development in such Federation subjects as Moscow, Sverdlovsk region, Irkutsk region, Kaluga region, Samara region, Penza region work actively. There are regions where institutes for development do not come out at all; only laws on innovation activity exist in these kinds of regions.

Today the question most difficult and demanding the solution is performance appraisal of institutes for development. Main purposes and objectives of institutes for development are stated in laws on the basis of which they are created, and also in other regulations and corporate documents (provisions, memorandums, strategy). The specified documents usually describe the general provisions concerning the creation and activity of the institutions, the principles of selection and financing of projects, procedures of investment of temporarily available funds, forms of control and supervision of their activity. As for standards for evaluation of the efficiency of institutes for development, they are not usually defined.

There are several criteria for assessing the quality of work of institutes for development. Firstly, it is thanks to their activities macro - microeconomic and institutional changes; secondly is their smart use of state resources.

The performance results of institutes for development according to their impact on socio-economic development can be divided into two groups. The first group of results - direct change of economic growth parameters or social development as a result of realization of specific projects in investment, innovation, external economic, infrastructure or social spheres. These results can be estimated through indicators of economic growth, growth of the investment amount, dynamics of export and import substitution, amount of production and its structure, etc. The second group is the changes in the market conditions, creating preconditions for positive socio-economic changes. The changing of parametric variation of the national financial market should be used as one of such results. It should be used by the increase (decrease) of a share of loans and credits attracted by the companies within the country; venture growth investment, positive bank loan dynamics granted to small business enterprises, etc. [6]

Table 4

Efficiency assessment indicators of regional development institutions

\begin{tabular}{|l|l|}
\hline Unit of assessment & \multicolumn{1}{c|}{ Indicators } \\
\hline $\begin{array}{l}\text { Intensity of } \\
\text { innovation in } \\
\text { production }\end{array}$ & $\begin{array}{l}\text { Level of patent activity } \\
\text { Level of innovation activity of the } \\
\text { industrial enterprises } \\
\text { Share of innovation goods, works and } \\
\text { services }\end{array}$ \\
\hline $\begin{array}{l}\text { Performance } \\
\text { intensity in society }\end{array}$ & $\begin{array}{l}\text { Inflow/outflow of high potential staff } \\
\text { in the region (migration level) }\end{array}$ \\
\hline $\begin{array}{l}\text { Economic } \\
\text { development }\end{array}$ & $\begin{array}{l}\text { Investment behaviour into fixed capital } \\
\text { Dynamics of Gross Regional Product } \\
\text { Dynamics of industrial production }\end{array}$ \\
\hline
\end{tabular}

In our opinion, the first group of indicators is more applicable for evaluation of regional development institutions, whereas for evaluation of Federal institutions (generally they are financial) should be used the second one. We divided indicators for assessing performance of regional devel- 
Groups of regions according to the resulting indicators

\begin{tabular}{|l|l|l|}
\hline \multicolumn{1}{|c|}{ Leaders } & \multicolumn{1}{|c|}{ Regions with average indices } & \multicolumn{1}{c|}{ Outsiders } \\
\hline St. Petersburg & Regions: Bryansk, Vladimir, Ivanovo, Kursk, & Regions: Kostroma, Smolensk, Arkhangelsk, \\
Moscow region & Lipetsk, Oryol, Ryazan, Tambov, Tula, & Vologda, Murmansk, Pskov, Kirov, Irkutsk, \\
Tomsk region & Novgorod, Astrakhan, Volgograd, Rostov, & Omsk, Amur, Magadan, Sakhalin \\
Samara region & Orenburg, Penza, Saratov, Ulyanovsk, Kurgan, & Republics: Karelia, Komi, Kalmykia, \\
Moscow & Kemerovo & Dagestan, Ingushetia, the Kabardino- \\
Republic of Tatarstan & Edges: Stavropol, Altai, Krasnoyarsk, Seaside, & Balkarian, Karachay-Cherkess, North Ossetia \\
Kaluga region & Khabarovsk, & - Alania, Chechen, Mary, El, Udmurt, Altai, \\
Leningrad region & Republics: Nenets, Khanty-Mansi, & Buryatia, Tyva Khakassia, Sakha (Yakutia) \\
Belgorod region & Republics: Adygea, Bashkortostan, Mordovia, & Jewish autonomous region \\
Nizhny Novgorod Kegion & & Chukotka Autonomous Area, Yamalo-Nenets \\
Novosibirsk region & & Autonomous Area, Transbaikal, Kamchatka \\
Sverdlovsk region & & edges \\
Krasnodar Krai & & \\
Chelyabinsk region & & \\
Perm Krai & & \\
Voronezh region & & \\
Yaroslavl region & & \\
Kaliningrad region & \\
Chuvash Republic & \\
Tver region & & \\
\hline
\end{tabular}

opment institutions into three groups. Indicators of intensity of innovation in production estimate the total indicators of innovation activity. Level of patent (inventive) activity, level of innovation activity of the industrial enterprises and share of innovative manufacturing in the total amount of industrial output are belonged to this group of indicators. In our opinion, intensity of innovations in society can be estimated through high potential staff, i.e. through an indicator of level of the population movement (tab. 4).

The sustainable development of regional institutions provides improvement of the main socio-economic indexes of territory development. For such assessment we to assume to use the indicators of investment behavior, Gross Regional Product and overall production. The generalized group of regions according to performance indicator is presented in table 5 .

In summary, among the regions being in the group of leaders on the resulting indicator, there are 12 out of 22 of federal subjects of Russia that use various institutes and instruments for development most actively.

The conducted research allows to draw the following conclusions.

1. The organizing of the institutes for development and institutional environments in regions of the Russian Federation is the complexity and inconsistent issue. There are a few reasons: firstly, it is an absence of united scientific and reasonable theoretical methodological base, methodical and practical development in the field. Secondly, it is the lack of integration communications be- tween science, business, education and the power. Absence of consensus between these groups results in lack of consistency in organizing and development of regional institutions. It is necessary required to develop mutual integration and build mechanisms of interaction of science, the power, education and business.

2. In Russia the federal institutes predominate in modern three-level structure of institutes for development. The preponderating part in this three-tier structure belongs to the federal institutes a share which makes $70 \%$. At the same time, the territorial differentiation in regional institutes' location occurs.

3. Regional development institutes gives new incentive for development of the regional economy and allows the authorities to influence tendencies of regional development more effectively. The assessment of regional institutions allowed to allocate two types of regions: those with a high level of the development of institutions of regional growth and regions without institutes for development. It is necessary to create, introduce and transform different market development institutions. At the same time, the institutions have to be rather various and provide a multi-purpose orientation of territorial development [12].

4 . There is an issue between a strategy of development of the region and narrow tasks of institutes for development. The system of regional institutes for development has to be integrated. It is not simply an instrument of state policy, but it aims at essential changing of economics, and so has the strategic character. 
The work is performed with support of the basic scientific research program of UB RAS, the project No. 12-P-7-1001 «New tools and methods of forecasting of innovative and technological development of regions", carried out within the framework of Presidium of RAS program No. 34 .

\section{References}

1. Nabiullina E. (2007). O zadachakh institutov razvitiya po diversifikatsii ekonomiki Roossiyskoy Federatsii. Tezisy vystupleniya na zasedanii Pravitelsta Rossiyskoy Federatsii 11 oktyabrya 2007 [Problems of development institutions to diversify the economy of the Russian Federation. Abstracts of presentations at the meeting of the Government of the Russian Federation, 11 October 2007]. Available at: http:www.economy.gov.ru

2. Popov E. V., Vlasov M. V., Simakhina M. O. (2010). Instituty regionalnogo razvitiya ekonomiki znaniy [Institutions of regional development of the knowledge economy]. Regionalnaya ekonomika. Teoriya i praktika [Regional Economics. Theory and Practice], 4, 2-7.

3. Poltavsky P. A. (2010). Institutsionalniy podkhod $\mathrm{k}$ gosudarstvennomu regulirovaniyu deyatelnosti v innovatsionnoy sfere [The institutional approach to state regulation of activities in the sphere of innovations]. Vestnik Chellyabinskogo gosudarstvenogo universiteta [Bulletin of the Chelyabinsk State University], 5 (186). Economy. MY. 25, 13-17.

4. North D. (1993). Instituty i ekonomicheskiy rost: istoricheskoye vvedenie [Institutions and Economic Growth: a historical introduction]. THESIS, Volume 1, Issue. 2, 73.

5. Rossiyskie instituty razvitiya ekonomiki znaniy [Russian development institutions: a regional perspective]. (2010). Expert RA, December 17. Available at: http://raexpert.ru/researches/regions/ros_evolution/

6. Agency for Housing Mortgage Lending: Available at: http://ahml.ru/

7. Infrafond MER: Available at: http://www.rusventure.ru/

8. Ivanter V., Uzyakov M., Shurov A. (2013). Trebovaniya k promyshlennoy politike v investitsionnom stsenarii [Requirements for industrial policy in the investment scenario]. Economist. 5, 3-17.

9. Obzory investitsionnoy politiki OESR: Rossiyskaya Federatsiya. Tezisy vystupleniya na zasedanii Pravitelstva Rossiyskoy Federatsii 11 oktyabrya 2007 [OECD Investment Policy Reviews: Russian Federation. Increased transparency policy]. Ministerstvo ekonomicheskogo razvitiya rossiyskoy Federatsii [Organization for Economic Cooperation and Development]. Available at: http:// oecdru.org/

10. Rating of innovative activity of regions 2011. National Association of innovation and the development of information technology (NAIR). Available at: http://www.nair-it.ru/

11. O deyatelnosti finansovykh institutov razvitiya. Materialy k zasedaniyu soveta po konkurentnosposobnosti I predprinimatelstvu pri pravitelstve RF [The activities of financial institutions. Materials for the meeting of the Council on Competitiveness and Entrepreneurship under the Government of the Russian Federation]. Available at: http://rudocs.exdat.com/navigate/index-95602/

12. Tatarkin A.I. (2012). Formirovaniye regionalnyh institutov prostranstvnogo ravitiya Rossiyskoy Federatsii [The formation of regional spatial development institutes of the Russian Federation]. Ekonmicheskiye i stotsialnyye peremeny. Faktry, tendentsii, prognoz [Economic and social changes: facts, trends and outlook], 6 (24), 42-59.

\section{Information about the authors}

Tatarkin Aleksandr Ivanovich (Yekaterinburg, Russia) - Member of the Academy of Sciences, Doctor of Economics, Professor, Director of the Institute of Economics, Ural Branch of the Russian Academy of Sciences (29 Moscovskya st., Yekaterinburg, 620014, Russia, e-mail: tatarkin_ai@mail.ru).

Kotlyarova Svetlana Nikolaevna (Yekaterinburg, Russia) - PhD in Economics, Head of the Sector at the Institute of Economics, Ural Branch of the Russian Academy of Sciences (29 Moskovskya st., Yekaterinburg, 620014, Russia, e-mail: sv_gavrilova@mail.ru). 